\title{
Reproductive and population dynamics of the Bay whiff Citharichthys spilopterus Günther, 1862 (Pleuronectiformes: Paralichthyidae) in the Mamanguá Inlet, Rio de Janeiro, Brazil
}

\author{
June Ferraz Dias, Carla Bertolucci Fiadi, \\ Helcy Lylian Nogueira Silbiger, and Lucy Satiko Hashimoto Soares
}

Bay whiffs, Citharichthys spilopterus, were sampled in Mamanguá Inlet between March 1990 and March 1992 for evaluation of its reproductive dynamic. Bay whiffs presented a crescent gradient of abundance from the deepest to the shallowest stations. The mean total length by oceanographic station showed a clear tendency of a relationship between bigger sizes and higher depths. Males predominated along the studied period and on the smallest length groups. Higher values of alometric condition factor, gonadosomatic relationship and spawning stage of maturity indicated a higher degree of development of the gonads on March and November. Histological analysis showed spawning females in March and May 1990 in the stations closer to the mouth of the Inlet, and spawned females with old post-ovulatory follicles and high frequency of atresia at shallow stations, suggesting a migration to shallow and protected areas after spawning. Length of first gonadal maturation was $117 \mathrm{~mm}$ TL. We could conclude that $C$. spilopterus completes its life cycle within the Mamanguá Inlet, spawning during autumn (March to May) and possibly November.

Espécimes de Citharichthys spilopterus foram coletados no saco do Mamanguá entre março de 1990 e março de 1992 para avaliação de sua dinâmica populacional e reprodutiva. Os linguados apresentaram um gradiente crescente de abundância da estação mais profunda para a mais rasa. A média do comprimento total por estação oceanográfica mostrou uma tendência de relação entre maiores tamanhos e maiores profundidades. Os machos foram predominantes durante o período de estudo e nas menores classes de comprimento. Altos valores de fator de condição alométrico, relação gonadossomática e estádios mais adiantados de maturidade gonadal indicaram alto grau de desenvolvimento das gônadas em março e novembro. Análises histológicas mostraram fêmeas desovantes em março e maio nas estações próximas à boca do saco, e fêmeas desovadas com folículos pós-ovulatórios velhos e alta freqüência de atresia em estações rasas, sugerindo a migração para áreas rasas e protegidas após a desova. O comprimento de primeira maturação gonadal foi $117 \mathrm{~mm}$ de comprimento total. Podemos concluir que C. spilopterus completa seu ciclo de vida no saco do Mamanguá, desovando durante o outono (entre março e maio) e possivelmente também em novembro.

Key words: Population structure, reproduction, gonadosomatic relationship, gonadal maturation, Southeast Brazil.

\section{Introduction}

The Bay whiff Citharichthys spilopterus Günther, 1862 is a small flatfish, Family Paralichthyidae, distributed from New Jersey (USA) to Rio Grande do Sul (Brazil), and is captured frequently in shallow coastal and estuarine areas (Figueiredo \& Menezes, 2000). Bernardes (1995) classified the Bay whiff as a permanent component of the community structure of the Mamanguá Inlet, based on its abundance and occurrence over all the samples collected. Chaves \& Vendel (1997) also classified C. spilopterus as resident in the mangrove areas of Guaratuba Bay, Southeast Brazil.
The main food items of this species are Caridea shrimps and fishes (Magro, 1996; Lucato, 1997; Chaves \& Serenato, 1998), although Toepfer \& Fleeger (1995) found a clear ontogenetic feeding shift from zooplanktonic copepods to mysid shrimps along the development and Lucato (op. cit.) reported a big similarity of the diet between young and adult forms. Day and dawn are the periods of higher frequency of fresh preys in the stomachs of the Bay whiffs collected in the Mamanguá Inlet (Magro, op. cit.).

Previous studies on reproductive indicators of Citharichthys species (C. arenaceus and C. spilopterus), as morphological description, gonadosomatic index and condi- 
tion factor, verified its reproductive activity during late spring and early austral summer at Guaratuba Bay (Paraná, Brazil) (Chaves \& Vendel, op. cit.), although the data and results for these two species were pooled. Ichthyoplankton surveys collected Citharichthys larvae from September to December in the Gulf of Mexico and from October to April in North Carolina, during boreal autumn and winter (Tucker, 1981).

The Mamanguá Inlet is an environmental protected area, with low anthropogenic influences or impacts. Information concerning reproductive biology of the species that inhabit Mamanguá Inlet could be an essential biological tool for management. Moreover, this study provides information about the population structure and reproductive dynamics of Citharichthys spilopterus in the Mamanguá Inlet.

\section{Material and Methods}

Survey samples were conducted as part of an interdisciplinary project, and were collected between March 1990 and March 1992 with an otter trawl (40 mm mesh size in the wings and $25 \mathrm{~mm}$ in the centre) operated on board of the R. V. Veliger 2, from Instituto Oceanográfico - Universidade de São Paulo, for $5 \mathrm{~min}$., with speed of 2 knots, and with a beach seine $(30 \mathrm{~m}$ long, $12 \mathrm{~mm}$ mesh size in the wings and $10 \mathrm{~mm}$ in the centre). The samples were collected in March, May, August and November 1990; May and September 1991; and March 1992, in 5 oceanographic stations established along the Mamanguá Inlet (Station 5 was not sampled in March/90) and 4 stations in the margin of the beaches (Fig. 1).

The Mamanguá Inlet is a closed area of $8 \mathrm{~km}$ extension by $1.5 \mathrm{~km}$ width, with a maximum depth of $10 \mathrm{~m}$ (Ambrósio Jr et al., 1991). The low energy processes characterize it, with low intensity of tidal currents and mud deposition. In order to describe the hydrographic conditions of the area, the temperature of the surface and bottom water was measured with reversion thermometers, water for salinity evaluation was taken with Nansen bottles and determined by electric conductivity ratio using an inductive salinometer.

A total of 541 specimens of Bay whiff were examined, 513 collected by the otter trawl. Voucher specimens (CISP 01) were deposited in the ichthyological collection of the Laboratório de Ecologia da Reprodução e do Recrutamento de Organismos Marinhos - from Instituto Oceanográfico Universidade de São Paulo. Total length of each fish was measured to the nearest millimeter (TL); total weight (TW) was measured in grams; and sex was identified macroscopically. The ovaries (OW) and testes were weighed in grams. Population structure by length and gender were analyzed based on distribution and abundance data by length groups, and the sex ratio was estimated by month and by length classes. Statistical differences were tested by Chi-square $\left(\chi^{2}\right)$.

Condition of the Bay whiffs were accessed by total weighttotal length relationship, estimated based on the potential model $\left(\mathrm{TW}=\mathrm{ax} \mathrm{TL}{ }^{\mathrm{b}}\right)$, and the alometric condition factor $(\mathrm{K})$ was calculated to females and males by the expression: $\mathrm{K}=$ $\left(\mathrm{TW} / \mathrm{TL}^{\mathrm{b}}\right) * 10^{4}$ and $\mathrm{K}^{\prime}=\left((\mathrm{TW}-\mathrm{OW}) / \mathrm{TL}^{\mathrm{b}}\right) * 10^{4}$, where $\mathrm{b}=$ the

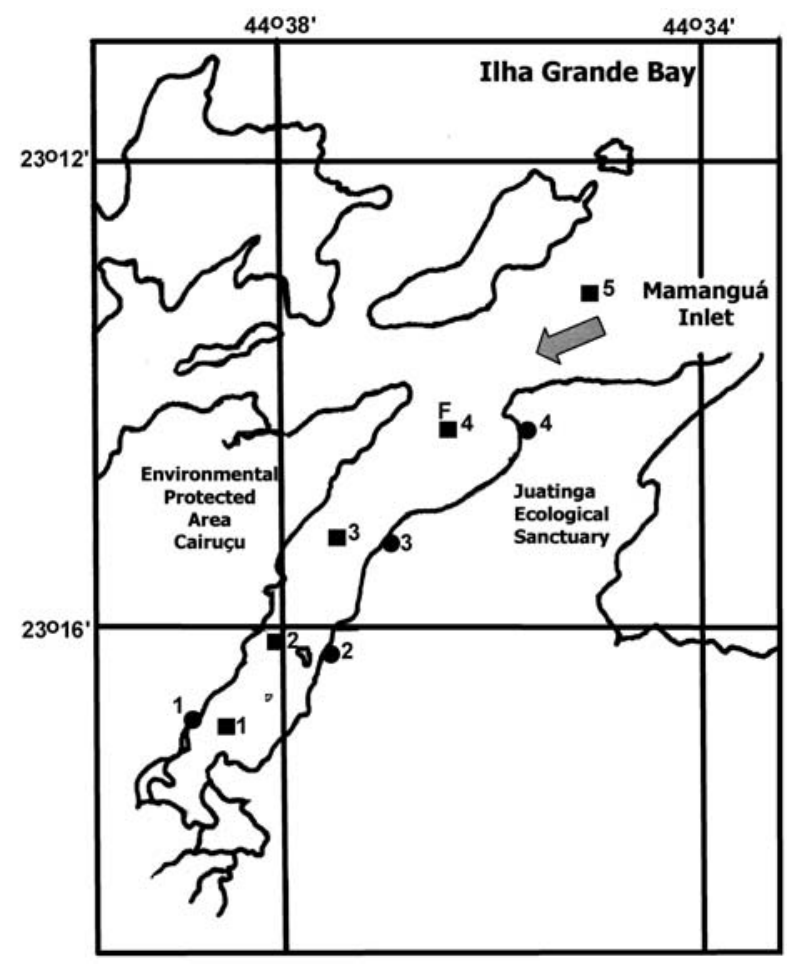

Fig. 1. Sampled area for Citharichthys spilopterus in the Mamanguá Inlet, Rio de Janeiro, Brazil. Modified from Bernardes (1995). Five oceanographic stations and four satations in the margins of the beaches are indicated with numbers.

slope of the total weight-total length relationship, and differences between two slopes were tested ( $t$-test, Zar, 1974). Differences between $\mathrm{K}$ and $\mathrm{K}$ ' (= "K) were used as an additional indicator of the reproductive period (Scott, 1979; Vazzoler, 1996).

Testes were classified macroscopically as immature or mature/ripe (Rickey, 1995), based on the gelatinous and folded aspect or whitish color, and tested by Chi-square $\left(\chi^{2}\right)$. Ovaries were classified according to a macroscopic evaluation based on qualitative characters according to Dias et al. (1998). In order to compare ovaries macroscopically and microscopically, mainly classified as "developing", that includes major source of errors (Dias et al., op. cit.), $44 \%$ of selected randomly ovaries collected in March 1990 and $62 \%$ collected in May 1990 were preserved in $4 \%$ buffered formalin-water solution and processed for histology. A section of the medium third of the ovaries was cut, dehydrated in an alcohol series, clarified in xilol and embedded in paraffin. Cuts were $5 \mu \mathrm{m}$ thick and stained in hematoxilin and eosin. The microscopic classification was based on Dias et al. (op. cit.) and Yoneda et al. (2002) considering the frequency of occurrence of the oocytes in different developmental stages and the presence of postovulatory follicles. Two stages of follicular atresia $(\alpha$ or older $=\beta+\gamma+\delta$ ) were also remarked. No measurements of the oocytes were done based on histological slides to avoid bias. Potential batch fecundity was estimated by counting the most advanced phase of the oocytes (hydration or migra- 

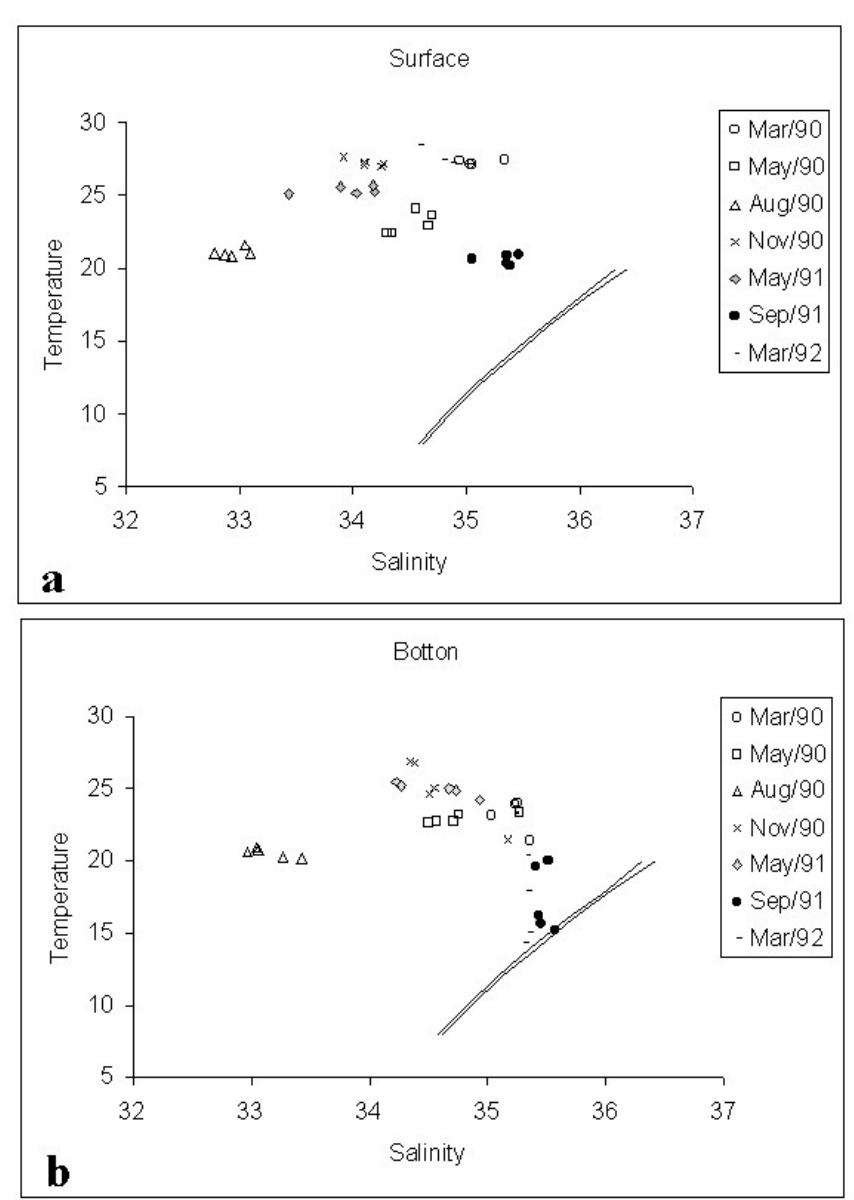

Fig. 2. T-S diagram for the Mamanguá Inlet based on (a) surface and (b) bottom data of temperature and salinity from March 1990 to March 1992. Lines represent the values of the South Atlantic Central Waters, calculated from coefficients of the mean T-S expressions based in Miranda (1985).

tory nucleus stage) dissociated from, at least 3 pieces around $2 \%$ of the ovarian weight, from 8 pre-hydrated (final C stage) or hydrated females (D stage).

The gonadosomatic index was calculated considering maturity stages separately, as GSR $=(\mathrm{OW} /(\mathrm{TW}-\mathrm{OW}))^{*} 10^{2}$. Only females were used to this estimation, because males may give less well-defined evaluation concerning macroscopic maturity stages and spawning season (West, 1990). Immature individuals were not considered in this estimation since their gonads present an insignificant weight in relation to the body weight and they could compromise the interpretation of the mean values. Temporal variations on population GSR indicate reproductive periods, based on the dynamics of the ovarian development and oocyte maturation (Vazzoler, 1996). Reproductive period was estimated by GSR, by the relative frequency of mature/spent females and by the presence of post-ovulatory follicles in the ovaries.

Average size at maturity was estimated for females, according to the logistic model described in DeMartini \& Lau (1999), using macroscopic and microscopic classification of the ovaries to separate immature individuals from the adult ones.

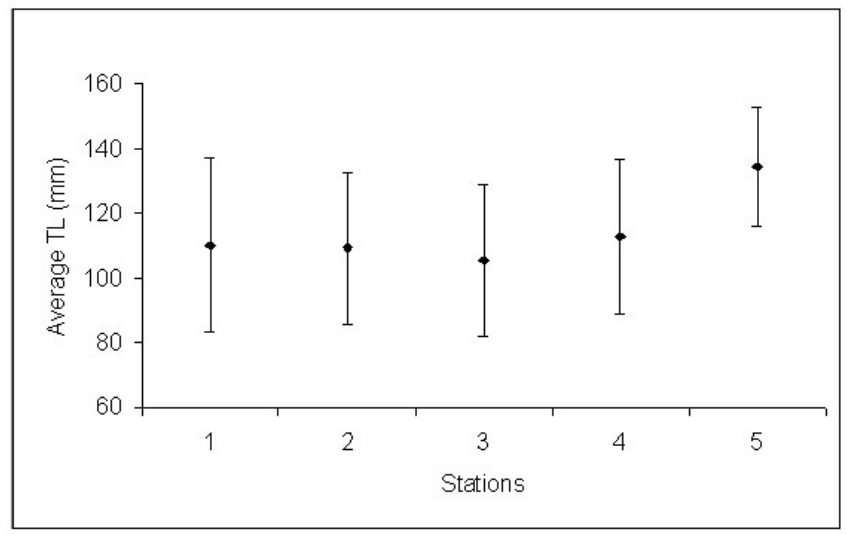

Fig. 3. Spatial variation of the average length of Citharichthys spilopterus in the Mamanguá Inlet. Bars= standard deviation.

\section{Results}

The T-S diagrams plotted for surface and bottom data collected show a picture of a two-layer stratified Inlet as a result of the influence of the intrusions of cold and salty water in the mouth of the Inlet in September 1991 and March 1992 (Fig. 2a-b). At these occasions, temperatures reached less than $15^{\circ} \mathrm{C}$ in the bottom. But, in the other months, the values of salinity and temperature indicate a mixed within the Inlet. The highest value of temperature in the bottom and in the surface was detected during November 1990, when the salinity was higher, while the lowest salinity values were registered during August 1990 in the Mamanguá Inlet.

Relative frequency of occurrence of these specimens along the Mamanguá Inlet presented a crescent gradient of abundance from the deepest to the shallowest stations, except November 1990 and March 1992 (Table 1). The highest CPUE by number $(\mathrm{N}=181)$ and weight (3111.9 g) occurred in May 1990. The beach seine captured 28 specimens, $95 \%$ in the inner and shallow station.

Specimens smaller than $70 \mathrm{~mm}$ total length occurred in March and August 1990, May and September 1991 (Table 2). The length frequency distribution did not show a clear modal progression by time, but the mean total length by oceanographic station presented a tendency of a relationship between bigger sizes and higher depths (Fig. 3). Both results suggest March and August 1990, and May and September 1991 as recruitment of the Bay whiffs to the net.

The total weight-total length coefficients confirmed alometric growth and did not differ significantly between months or sexes (males $\mathrm{y}=2 \mathrm{E}-06 \mathrm{X}^{3.3281}$; females $\mathrm{y}=2 \mathrm{E}-06 \mathrm{X}$ ${ }^{3.3414}$; total $\left.\mathrm{y}=2 \mathrm{E}-06 \mathrm{X}^{3.3281}\right)$. Considering the whole period, the slope of the total length-total weight relationship was higher than that estimated by Chaves \& Vendel (1997), suggesting that in the Mamanguá Inlet the specimens are heavier than in Guaratuba Bay.

Higher mean values of the alometric condition factor occurred in March and August 1990, and March 1992, indicating higher fitness in these periods of time (Fig. 4); "K values 
Table 1. Relative frequency of occurrence of C. spilopterus, along the Mamanguá Inlet, in the oceanographic stations. $\mathrm{N}$ $=$ number of specimens. Station 5 wasn't sampled in Mar/90.

\begin{tabular}{ccccccc}
\hline & ST1 & ST2 & ST3 & ST4 & ST5 & N \\
\hline Mar/90 & 34.4 & 25.8 & 21.5 & 17.2 & - & 92 \\
May/90 & 31.5 & 31.5 & 18.8 & 12.7 & 0 & 171 \\
Aug/90 & 36.4 & 28.6 & 13.6 & 15.0 & 1.4 & 133 \\
Nov/90 & 3.8 & 23.1 & 46.1 & 19.2 & 7.7 & 26 \\
May/91 & 19.4 & 25.0 & 22.2 & 13.9 & 13.9 & 34 \\
Sep/91 & 32.7 & 23.6 & 18.2 & 9.1 & 3.6 & 48 \\
Mar/92 & 20.0 & 30.0 & 40.0 & 0 & 0 & 9 \\
\hline Total & 32.8 & 29.6 & 20.9 & 14.6 & 2.1 & 513 \\
\hline
\end{tabular}

were bigger during March and November 1990, and March 1992, indicating the highest degree of development of the gonads, preceding spawning periods (Fig. 4).

From 541 specimens collected, 295 were males, 217 females and it was not possible to identify the sex of 29 individuals. Data concerning length frequency distribution for males and females show that males predominate in length groups smaller than $131 \mathrm{~mm}$ and the females in the other length groups (Fig. 5a). All specimens bigger than $170 \mathrm{~mm}$ total length were females. This species is gonochorist and this could be this result could be associated to different growth rates of males and females. Temporal analyses presented a significant predominance of males along the studied period (Fig. 5b).

From the males collected, $72 \%$ were adults and the differences between the number of immature and adult specimens were significant along the period (Fig. 6a). The proportion of females at different macroscopic stages of classification varied (Fig. 6b). Young immature females were collected all over the period, except November 1990, and mature ovaries were also present during all the period, with picks in March and November 1990. Spawning activity was identified only in May 1990 by macroscopic classification of the ovaries. The average size at first gonadal maturation $\left(\mathrm{L}_{50}\right)$ was $117 \mathrm{~mm}$ and all females with total length higher than $152 \mathrm{~mm}$ were mature.

A total of 69 ovaries from March and May 1990 were histologically analyzed. Oocytes in different developmental phases were present simultaneously (Fig. 7), suggesting an asynchronic development. Microscopic classification of these ovaries showed a maximum of $50 \%$ error of macroscopic clas-

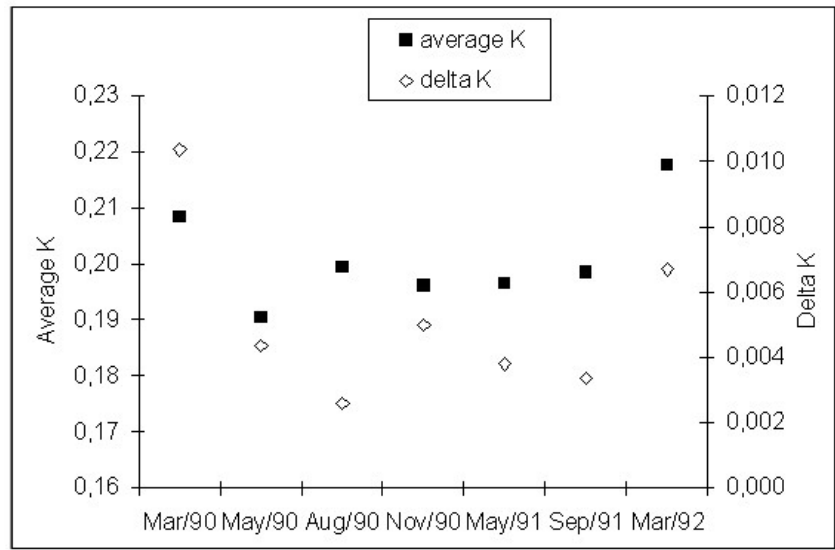

Fig. 4. Mean values of the alometric condition factor $(\mathrm{K})$ and "K estimated to C. spilopterus in the Mamanguá Inlet.
Table 2. Temporal variation of the length frequency distribution of Bay whiff in the Mamanguá Inlet. $\mathrm{N}=$ number of specimens.

\begin{tabular}{ccccccccc}
\hline & $<71$ & $71 / 90$ & $91 / 110$ & $111 / 130$ & $131 / 150$ & $151 / 170$ & $>170$ & $\mathrm{~N}$ \\
\hline Mar/90 & 4.3 & 26.9 & 28.0 & 19.3 & 14.0 & 7.5 & 0 & 93 \\
May/90 & 0 & 14.4 & 37.0 & 22.1 & 17.1 & 7.7 & 1.7 & 181 \\
Aug/90 & 2.9 & 14.3 & 37.1 & 20.7 & 16.4 & 7.9 & 0.7 & 140 \\
Nov/90 & 0 & 11.5 & 50.0 & 11.5 & 11.5 & 15.4 & 0 & 26 \\
May/91 & 11.1 & 22.2 & 16.7 & 19.4 & 25.0 & 5.6 & 0 & 36 \\
Sep/91 & 14.5 & 38.2 & 36.4 & 5.5 & 0 & 1.8 & 3.6 & 55 \\
Mar/92 & 0 & 0 & 30.0 & 30.0 & 30.0 & 10.0 & 0 & 10 \\
\hline Total & 3.7 & 19.0 & 34.6 & 19.0 & 15.2 & 7.4 & 1.1 & 541 \\
\hline
\end{tabular}

sification (Table 3). Maturity stage A (immature) presented the lowest percentage of error $(7.7 \%)$, whereas stages D and $\mathrm{E}$ (hydrated and spawned) showed $100 \%$ error, inducing to a non-identification of the spawning process. Based on this table, the percentages of different maturity stages were recalculated for March and May 1990 in each oceanographic stations (Fig. 8) and it was possible to identify higher values of spawning females, including those classified as hydrated and spawned, in the stations number 3 and 4, the deepest ones. On the other hand, there were no spawning females and only spawned ones, with old post-ovulatory follicles (Fig. 7 e-f), in the shallowest stations (1 and 2), suggesting a migration to shallow waters after spawning process on May 1990.
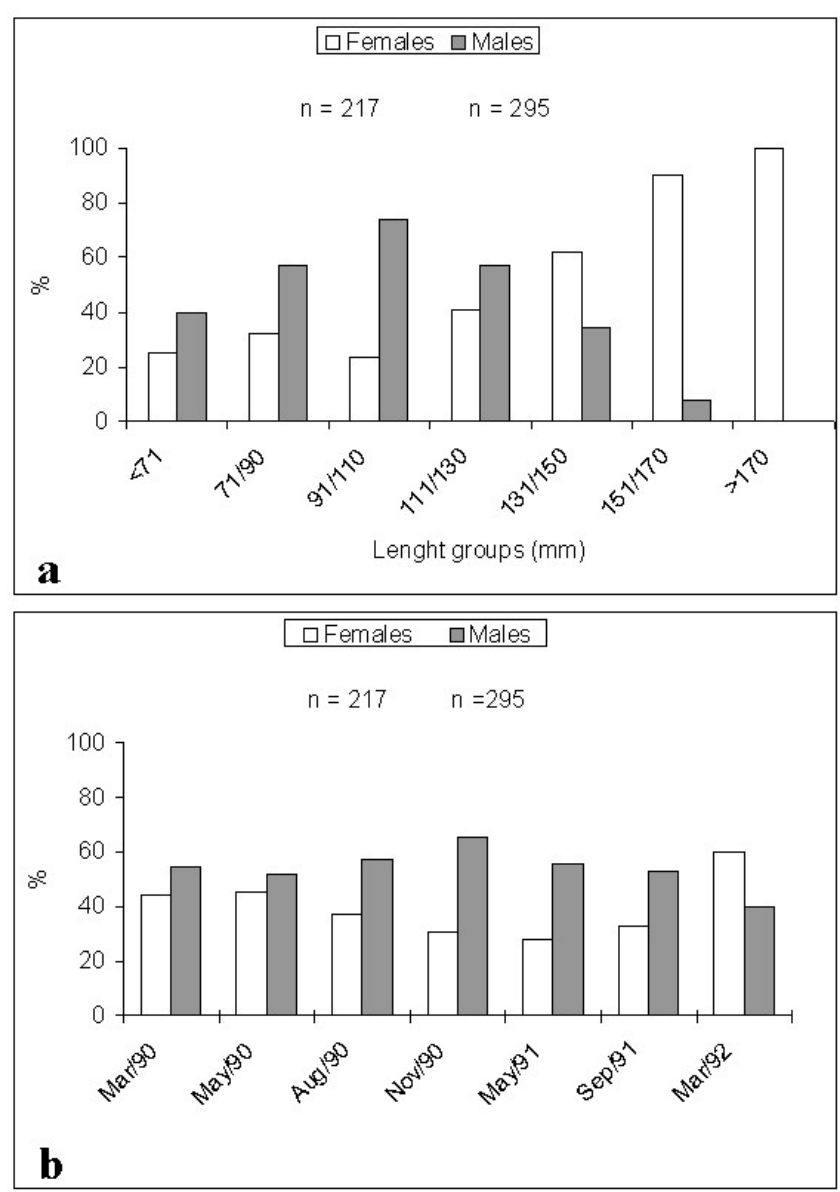

Fig. 5. Analyses of the sex ratio of C. spilopterus: a) by length groups and b) by months. 
Table 3. Macroscopic vs. microscopic classification of the ovaries of C. spilopterus collected in the Mamanguá Inlet. Bold $=$ percentages of setting right evaluation of the maturity stages. E-B, E-C and E-D had post-ovulatory follicles but were characterized by other oocytes stages.

\begin{tabular}{cccccccccc}
\hline Microscopic stages & A & B & C & D & E-B & E-C & E-D & Total & \% Error \\
\hline Macroscopic stages & & & & & & & & & \\
A & $\mathbf{1 2}$ & 1 & 0 & 0 & 0 & 0 & 0 & 13 & 7.7 \\
B & 2 & $\mathbf{5}$ & 10 & 0 & 7 & 4 & 0 & 28 & 82.1 \\
C & 0 & 3 & $\mathbf{9}$ & 3 & 0 & 6 & 5 & 26 & 65.3 \\
D & 0 & 0 & 1 & $\mathbf{0}$ & 0 & 1 & 0 & 2 & 100.0 \\
Total & 14 & 9 & 20 & 3 & 7 & 11 & 5 & 69 & 100.0 \\
\hline Atresic oocytes & 0 & 17 & 18 & 1 & & & & 36 & \\
\hline
\end{tabular}

High rates of $\alpha$ and old atresia in the ovaries were found mainly in the shallowest stations, and during May 1990 the maximum rate of atresia in the follicles per females reached 80 $\%$ of the oocytes (Fig. 7 b-d; Fig. 9 a-b); this characterizes processes of the end of the spawning season and reinforces the possibility of migration to shallow areas of the Inlet after spawning. In spite of the high rates of atresia, May 1990 presented also a high spawning activity, but the spawning females were in the deepest stations while spawned ones were in the shallowest stations of the Inlet.

Potential batch fecundity was calculated per gram of ovary weight per total length of the females, ranging from $7.10^{3}(141$
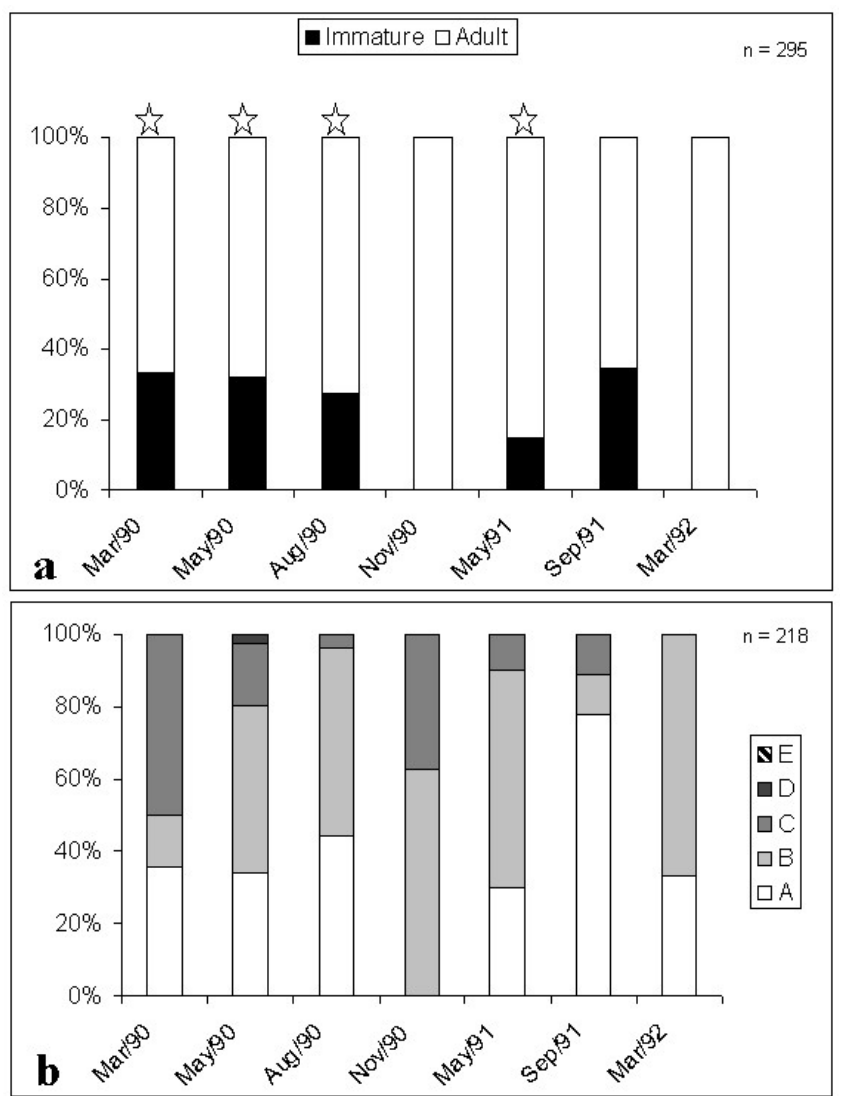

Fig. 6. Proportion of males (a) and females (b) of the Bay whiff in each macroscopic maturity stage considered in this study. Stars means significantly different - tested by Chisquare $\left(\chi^{2}\right)$. $\mathrm{mm} \mathrm{TL})$ to $61.10^{3}(155 \mathrm{~mm} \mathrm{TL})$ oocytes. The batch fecundity per gram of total weight ranged from 253 to 1552 oocytes. Afterwards, these ovaries used to the estimation of fecundity were processed for histological analysis, and some of them presented post-ovulatory follicles, indicating recent spawning. So, as the oocytes counted were pre-hydrated or hydrated, the potential batch fecundity considering females previously spawned showed relatively low number of oocytes (Fig. 10); in spite of this, the biggest female evaluated presented low values of potential batch fecundity and no signs of recent spawning.

Maximum mean values of GSR were found on March and November 1990, and March 1992, corresponding to the end of austral summer, for maturing/mature females ( $\mathrm{B}$ and $\mathrm{C}$ from macroscopic classification) (Fig. 11). Values on the GSR from March and November 1990 decreased, indicating spawning activity. This observation was confirmed by histological analysis.

\section{Discussion}

The rivers and the adjacent coastal waters conditioning the dynamics of estuaries and inlets. According to Castro Filho et al. (1987) and Castro \& Miranda (1998), there are 3 water masses over the Southeastern Brazilian Bight. The Coastal Water $(\mathrm{CW})$ is characterized by high temperatures and low salinity rates, whereas high temperature and salinity rates characterize the offshore Tropical Water (TrWa) of the Brazil Current, that flows southward. The South Atlantic Central Water (SACW) is a typical oceanic water mass and has temperatures below $18^{\circ} \mathrm{C}$ and salinities above 35 . When intruding in an intermittent mode onto the continental shelf, SACW occupies the bottom layer and mixes with the warmer and fresher Coastal Water $(\mathrm{CW})$. This water mass presents high nutrient values and is responsible for the enrichment processes of the water column along Southeastern Brazilian Bight, up to 10-fold increase in primary production (Aidar et al., 1993).

It was possible to notice that the Mamanguá Inlet has a small longitudinal gradient of salinity and low thermic stratification, except when the intrusions of South Atlantic Central Water (SACW) occurred, mainly in September 1991 and March 1992, whereas in cold months the interaction between the waters of the Inlet and SACW was nonexistent. During the intrusion situations, there was a clear influence of SACW in the bottom ichthyofaunal community structure, with high abundance and richness (Bernardes, 1995), reinforcing that the local dynamics and population structure are linked (Bailey, 1997). Variation in abundance of Citharichthys stigmaeus could be explained by low temperatures (Ehrlich et al., 1979), but it was not possible to relate the influence of SACW to abundance of the Bay whiffs in the Mamanguá Inlet.

Males of the Bay whiffs predominate in small length groups, following a pattern spread in many Pleuronectiform groups, as Paralichthyidae (Hippoglossina stomata), Pleuronectidae (Atherestes stomias, Pleuronichthys cornutus) and Soleidae (Solea lascaris) (Ichimaru \& Tashiro, 1994; Rickey, 1995; Ribeiro et al., 1999; Martinez-Munoz \& Ortega-Salas, 2001). 


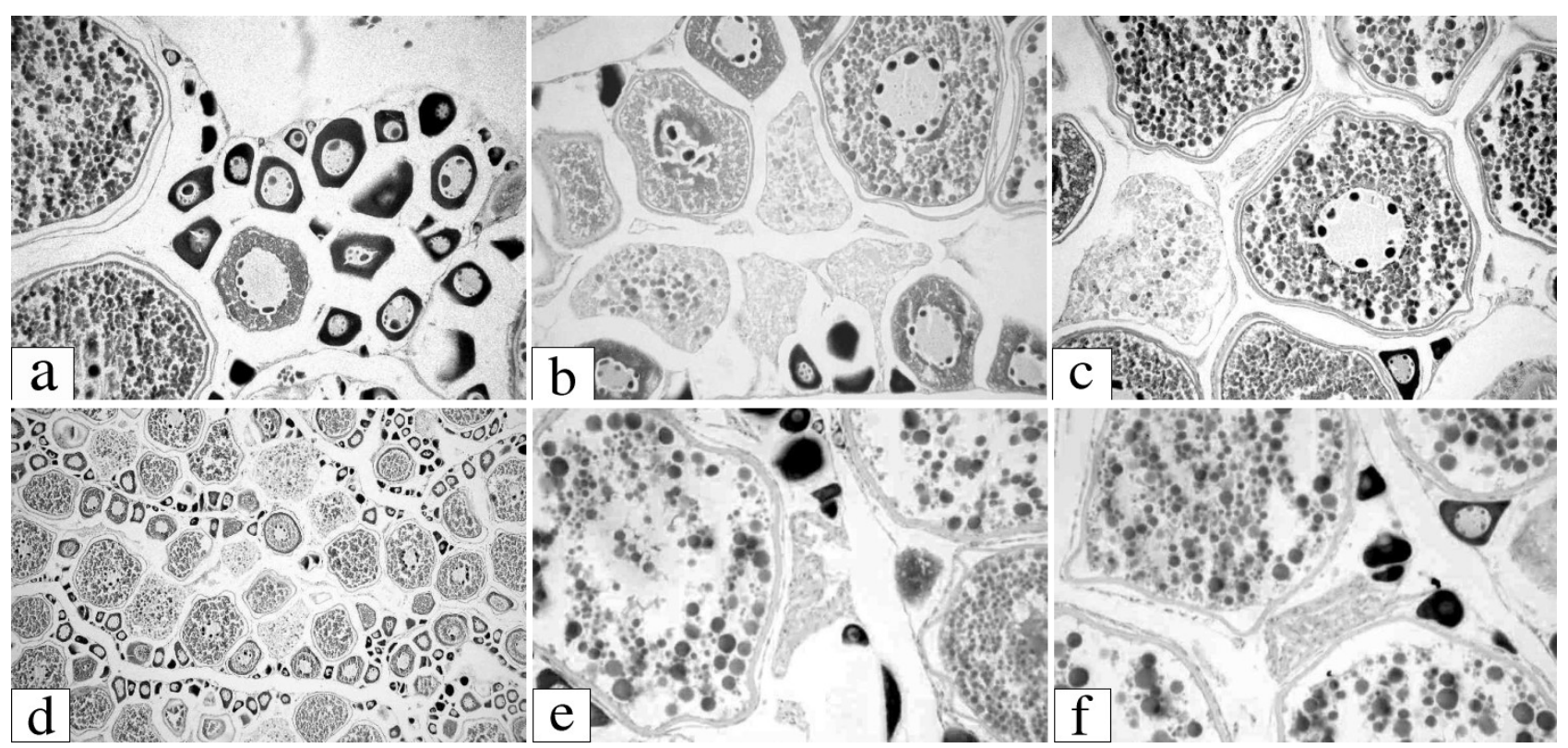

Fig. 7. Bay whiff oocytes at different developmental stages: a)chromatin-nucleolar $(\mathrm{CN})$, perinucleolar $(\mathrm{PN})$, yolk vesicles and mature stages (M), H-E, $40 \mathrm{X}$; b) yolk vesicles and secondary yolk stage, and $\alpha$ and $\beta$ atresia, $\mathrm{H}-\mathrm{E}, 40 \mathrm{X}$; c) primary yolk stage and early $\beta$ atresia, H-E, $40 \mathrm{X}$; d) high numbers of $\alpha$ and $\beta$ atresia, H-E, $10 \mathrm{X}$; e) and f) post-ovulatory follicles (POF), H-E, $40 \mathrm{X}$.
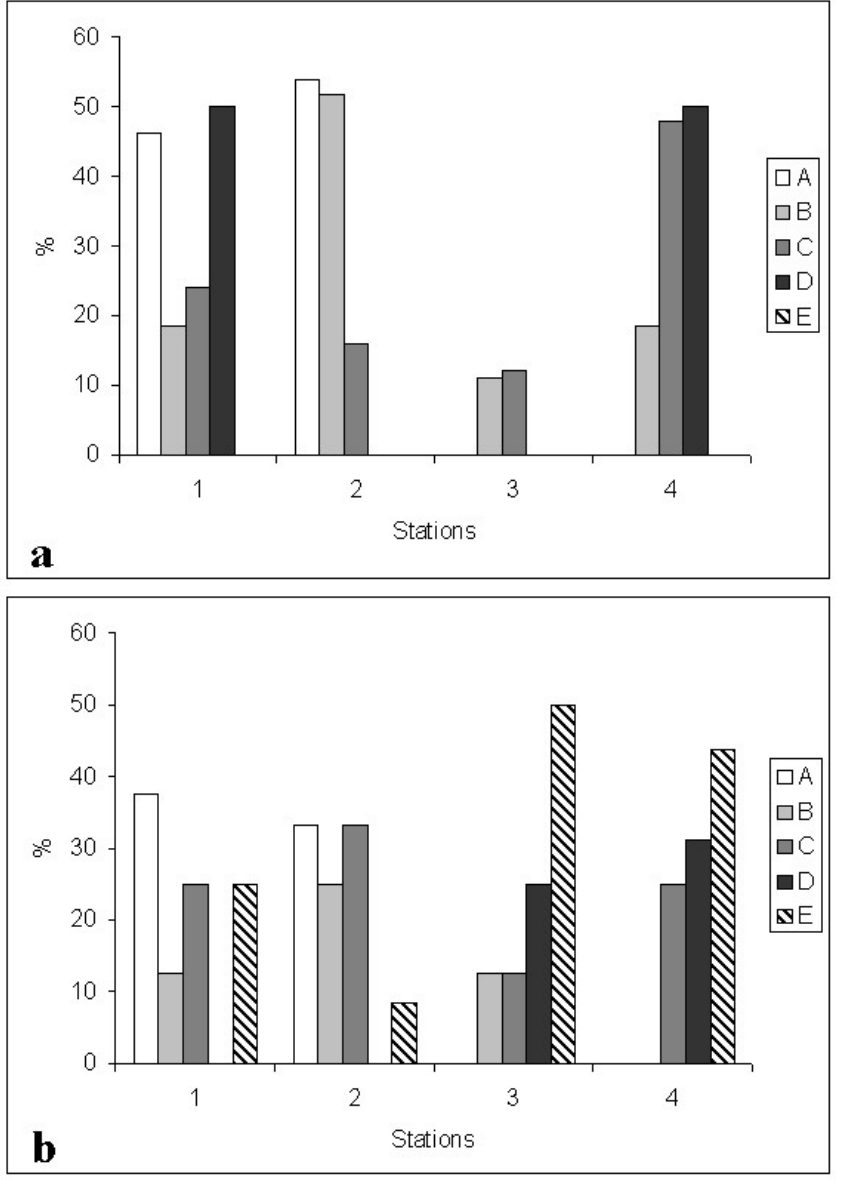

Fig. 8. Mean percentage of maturity stages assessed by (a) gross classification and (b) histological classification for $C$. spilopterus.
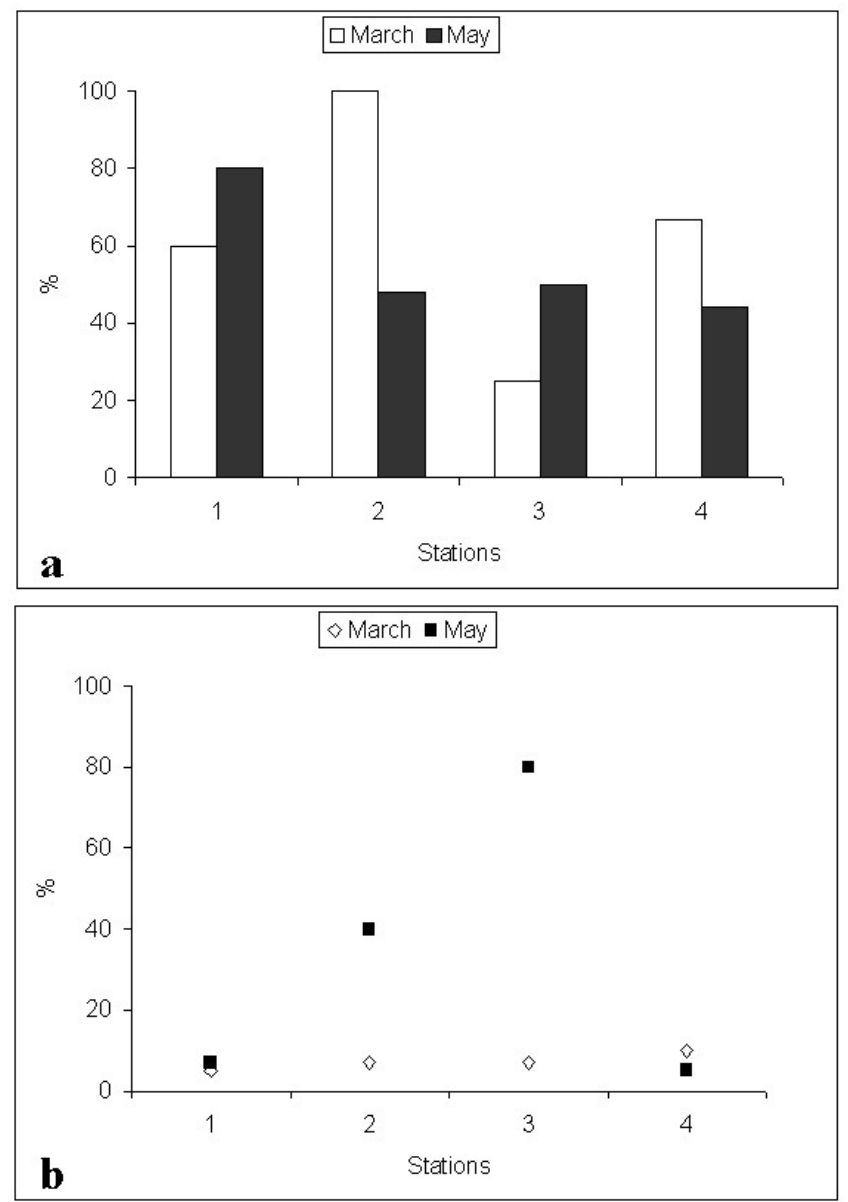

Fig. 9. Rates of follicular atresia in the ovaries of C. spilopterus captured at Mamanguá Inlet: a) percentage of females presenting á or older atresia; b) maximum rates of atresia by females in each oceanographic station on March and May 1990. 


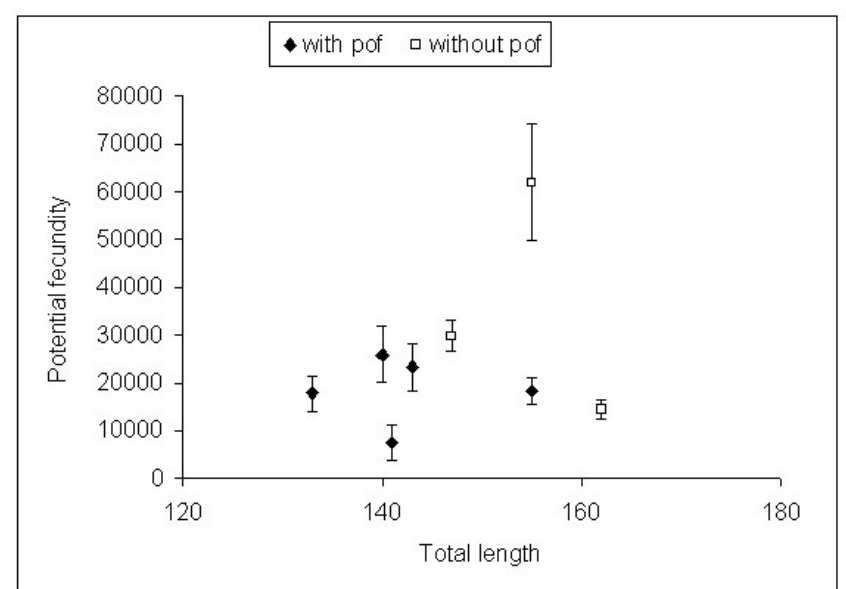

Fig. 10. Potential batch fecundity of the Bay whiff in the Mamanguá Inlet. Bars= standard deviation.

The indicators of the reproductive process applied here followed a clear pattern, concerning the development of the ovaries and maturation: higher values of GSR, " $\mathrm{K}, \mathrm{K}$, and the frequency of mature females accessed by macroscopic gross classification of the ovaries showed that maximum maturity and fitness were attained on November and March, it means spring and autumn. These results showed that the gonads had the highest weight in relation to the body, reflecting gonadal maturation as a result of the transference of vitelogenin from liver to oocytes. In September 1991 and March 1992, the higher values of "K and the increase of GSR match with the colder and rich South Atlantic Central Water influence in the Mamanguá Inlet. It is clear that the quantitative indicators based on rates of body and gonad weight minimize the subjectivity of field macroscopic staging, based on the size and appearance of the ovary only (Dias et al., 1998). Similar results were found by Chaves \& Vendel (1997) in Guaratuba Bay.

The length frequency distribution associated to the presence of females in all maturity stages of the ovaries suggest that there is a quasi-continuous recruitment of the Bay whiff along the year. The low catches in the mouth of the Inlet suggests there is no recruits from exogenous source and this fact allows interpretations of the dynamics of this flatfish population (Bailey, 1997).

The Mamanguá Inlet is used by the youngest and adults of this species, as a result of spawning in the Inlet. But the assessment of spawning periods should be based on detailed information about the ovaries and their development. Thus, the results concerning reproductive dynamics of Bay whiff in the area, based on microscopic evaluation of the ovaries, showed a more conclusive picture, in relation to the spawning period, in spite of the relative low number of gonads examined and taking into account the restrictions of only two seasons of histological studies. Based on microscopic analysis it was shown that $C$. spilopterus spawned in the Mamanguá Inlet during March and May 1990; these data can explain the decrease of GSR values from March to May 1990 (late summer - autumn), when the ovaries lost weight by releasing the oocytes. The macroscopic classification of the

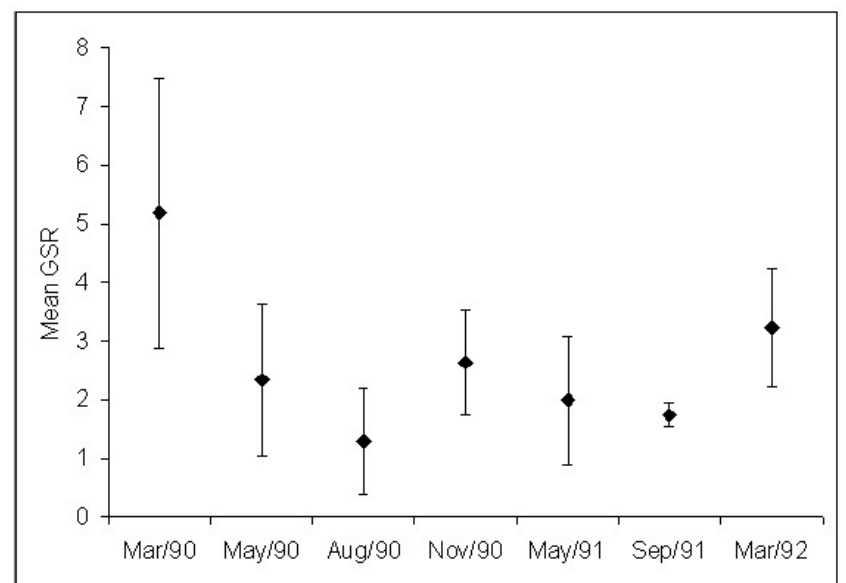

Fig. 11. Temporal variation of the mean values of the gonadosomatic relationship (GSR) of the Bay whiff in the Mamanguá Inlet. Bars= standard deviation.

ovaries did not detect spawned specimens and it could be explained by a low batch fecundity and high spawning frequency for this species. The low values of GSR were attained only at the end of the spawning season. In this case, the macroscopic misclassification could compromise the understanding of the spawning cycle of $C$. spilopterus. This kind of faillure was detected for other species as Prionotus punctatus in the Ubatuba region (Peres-Rios, 1995). Although it is an objective method, based in quantitative measurements, variations in gonadal weight and GSR give few indications of the processes involved in the dynamics of the ovaries (Scott, 1979), particularly in batch spawners.

Histology is an appropriate and precise method to identify the spawners, based on hydrated and post-ovulatory follicles, and can be applied to determine if fish is in spawning condition or if it has recently spawned (Hunter \& Macewicz, 1985), but as it is an expensive and time consuming methodology, it could be restricted to the maturity stages that are the major source of errors (West, 1990; Dias et al., 1998). So, the strategy of concentrating histological studies in gonads classified as B (in maturation), in which the appearance of the ovaries could lead to misinterpretations, was proved to be the right decision.

The spawning seasons estimated in this study for the Bay whiffs are not the same as estimated by Chaves \& Vendel (1997). The reasons involved more than differences of the regions (Mamanguá Inlet and Guaratuba Bay), the pooled species or sampling of the populations, but interpretation of the indicators. High values of GSR and other quantitative relative index are indicative of maximun maturation of the gonads, involving mature and hydrated oocytes, that is, cell phases with low duration in time, with consequent low frequency of occurrence in the samples. So, the spawning period must be related to the low values of the selected indicator based on ovary weights, which followed these high values of GSR or " $\mathrm{K}$, for example. The biological meaning is the loss of weight of the ovaries, due to the spawning process. In this sense, the main spawning period of the Bay whiffs of 
Guaratuba Bay and Mamanguá Inlet are closely related: from February to March and from March to May, respectively.

Bathymetric migrations are common to flatfishes (Rickey, 1995) and the major changes in distribution of the adults are related to spawning (Gibson, 1997). In this case, horizontal migrations and changes of local depth, from shallow to deeper waters, accompanied both, length and life cycle stages, as showed by the presence of females with old post-ovulatory follicles in the shallowest stations of the Inlet. The tidal movements can transport the larvae to this area, which receives the influence of the mangrove and small rivers, being a good environment for protection of the youngest and for recovering post-spawning females.

Based on the size frequency distribution and in the reproductive dynamics in the area, the scenario concerning reproductive dynamics of $C$. spilopterus could be understood. It was shown that the species completes its entire life cycle within the Mamanguá Inlet, migrating during its development to the deepest areas of the Inlet to spawn, during autumn, and after spawning, the females migrate back to the shallow areas inside the Inlet. Sampling designs monthly or fortnightly catches could verify if there are short-term processes involving the reproductive biology of the Bay whiffs that this study did not elucidate.

\section{Acknowledgments}

Thanks to the colleagues and participants of the Mamanguá Inlet Project who assisted in sampling and laboratory procedures, and to the crew of the R.V. Veliger 2 for all cooperation received. Special thanks to M.Sc. Marizilda Magro; to Valdemar Francisco de Oliveira Filho (FFLCH-USP) for English revision; and to two anonimous reviwers and to the editor's advices. Financial support for Mamanguá Inlet Project was provided by CIRM (Comissão Interministerial para os Recursos do Mar) and IOUSP (Instituto Oceanográfico da Universidade de São Paulo).

\section{Literature cited}

Aidar, E., S. A. Gaeta, S. M. F. Gianesella-Galvão, M. B. B. Kutner \& C. Teixeira. 1993. Ecossistema costeiro subtropical: nutrientes dissolvidos, fitoplâncton e clorofila-a e suas relações com as condições oceanográficas na região de Ubatuba, SP. Publicação especial do Instituto oceanográfico, São Paulo, (10):9-43.

Ambrósio Jr, O., C. Teixeira, L. B. Miranda, V. V. Furtado \& G. M. S. S. Brasil-Lima. 1991. Condições oceanográficas do Saco do Mamanguá. Simpósio sobre Oceanografia, 2. São Paulo, Instituto Oceanográfico, Universidade de São Paulo.

Bailey, K. M. 1997. Structural dynamics and ecology of flatfish populations. Journal of Sea Research, 37:269-280.

Bernardes, R. A. 1995. Estrutura e dinâmica da ictiofauna do Saco do Mamanguá (Paraty - R.J.). Unpublished PhD. Dissertation. Instituto Oceanográfico, Universidade de
São Paulo. São Paulo, 145 p.

Castro, B. M. \& L. B. de Miranda. 1998. Physical oceanography of the western Atlantic continental shelf located between $4^{\circ} \mathrm{N}$ and $34^{\circ} \mathrm{S}$ coastal segment (4,W), p. 209-251. In: Robinson, A. R. \& K. H. Brink (Eds.). 1998. The sea. John Wiley \& Sons, New York.

Castro Filho, B. M., L. B. de Miranda \& S. Y. Miyao. 1987. Condições oceanográficas na plataforma continental na largo de Ubatuba: varições sazonais em média escala. Boletim do Instituto Oceanográfico, São Paulo, 35(2):135-151.

Chaves, P. de T. da C. \& A. Serenato. 1998. Diversidade de dietas na assembléia de linguados (Teleostei, Pleuronectiformes) do manguezal da Baía de Guaratuba, Paraná, Brasil. Revista Brasileira de Oceanografia, 46(1):61-68.

Chaves, P. de T. da C. \& A. L. Vendel. 1997. Indicadores reprodutivos das espécies de Citharichthys Bleeker (Teleostei, Pleuronectiformes) na baía de Guaratuba, Paraná, Brasil. Revista Brasileira de Zoologia, 14(1):73-79.

DeMartini, E. E. \& B. B. Lau. 1999. Morphometric criteria for estimating sexual maturity in two snappers, Etelis carbunculus and Pristipomoides sieboldii. Fishery Bulletin, 97:449-458.

Dias, J. F., E. Peres-Rios, P. de T. da C. Chaves \& C. L. D. B. Rossi-Wongtschowski. 1998. Análise macroscópica dos ovários de teleósteos: problemas de classificação e recomendações de procedimentos. Revista Brasileira de Biologia, 58(1):55-69.

Ehlich, K.F., J. S. Stephens, G. Muszynski \& J. M. Hood. 1979. Thermal behavioral responses of the speckled sanddab, Citharichthys stigmaeus: laboratory and field investigations. Fishery Bulletin, 76(4):867-872.

Figueiredo, J. L. de \& N. A. Menezes. 2000. Manual de peixes marinhos do sudeste do Brasil. VI. Teleostei (5). Museu de Zoologia, Universidade de São Paulo, 116 p.

Gibson, R. N. 1997. Behaviour and the distribution of flatfishes. Journal of Sea Research, 37:241-256.

Hunter, J. R. \& B. J. Macewicz. 1985. Rates of atresia in the ovary of captive and wild northern anchovy, Engraulis mordax. Fishery Bulletin, 83:119-136.

Ichimaru,T. \& M. Tashiro. 1994. Age and growth of frog flounder (Honmeita type) Pleuronichthys cornutus in Ariake Sea. Bulletin of the Nagasaki Prefectural Institute of Fisheries, 20:1-8.

Lucato, S. H. B. 1997. Trofodiâmica dos peixes pleuronectiformes do canal de São Sebastião, São Paulo, Brasil. Unpublished MSc. thesis. Instituto Oceanográfico, Universidade de São Paulo. São Paulo, 110p.

Magro, M. 1996. Hábitos alimentares de peixes demersais da região do Saco do Mamanguá, Parati, Rio de Janeiro (Brasil). Unpublished MSc. thesis. Instituto Oceanográfico, Universidade de São Paulo. São Paulo, 235p.

Martinez-Munoz, M. A. \& A. A. Ortega-Salas. 2001. Growth and mortality of the bigmouth sole, Hippoglossina stomata Eigenmann \& Eigenmann 1890 (Pisces: Paralichthyidae), off the western coast of Baja California, Mexico. Bulletin of Marine Science, 69(3):1109-1119. 
Miranda, L.B. de. 1985. Forma da correlação T-S de massas de água das regiões costeira e oceância entre o cabo de São Tomé (RJ) e a ilha de São Sebastião (SP), Brasil. Boletim do Instituto Oceanográfico, 32(2):105-119.

Peres-Rios, E. 1995. Aspectos reprodutivos de Prionotus punctatus (Bloch, 1797) (Teleostei: Triglidae) na região costeira de Ubatuba, São Paulo, Brasil. Unpublished MSc. thesis. Instituto Oceanográfico, Universidade de São Paulo. São Paulo, 62 p.

Ribeiro, F., S. Ramos \& P. Santos. 1999. Evaluation of the amount of undersized sand sole Solea lascaris (Risso, 1810) caught in the Portuguese fisheries. Council Meeting of the International Council for the Exploration of the Sea, Stockholm, 8pp.

Rickey, M. 1995. Maturity, spawning, and seasonal movements of arrowthoot flounder, Atheresthes stomias, off Washington. Fishery Bulletin, 93:127-138.

Scott, D. B. C. 1979. Environmental timing and the control of reproduction in teleost fish. In: P.J. Miller (ed.). Fish Phenology: anabolic adaptiveness in teleosts. Symposia of the Zoological Society of London, n. 44. London, Academic Press, pp. 105-132.

Toepfer, C. S. \& J. W. Fleeger. 1995. Diet of juvenile fishes Citharichthys spilopterus, Symphurus plagiusa, and Gobionellus boleosoma. Bulletin of Marine Science, 56(1):238-249.
Tucker Jr, J. W. 1981. Larval development of Citharichthys cornutus, C. gymnorhinus, C. spilopterus, and Etropus crossotus (Bothidae), with notes on larval occurrence. Fishery Bulletin, 80(1):35-71.

Vazzoler, A. E. A. de M. 1981. Manual de métodos para estudos biológicos sobre populações de peixes. Crescimento e Reprodução. Brasília, CNPq/Programa Nacional de Zoologia, 108 p.

Vazzoler, A. E. A. de M. 1996. Biologia da reprodução de peixes teleósteos: teoria e prática. Maringá, EDUEM/SBI, 169 p.

West, G. 1990. Methods of assessing ovarian development in fishes: a review. Australian Journal of Marine and Freshwater Research, 41:199-222.

Yoneda, M.; Futagawa, K.; Tokimura, M.; Horikawa, H.; Matsuura, S. \& Matsuyama, M. 2002. Reproductive cycle, spawning frequency and batch fecundity of the female whitefin jack Kaiwarinus equula in the East China Sea. Fisheries Research, 57: 297-309.

Zar, J. H. 1974. Biostatistical analysis. New Jersey, Prentice Hall, 662 p.

Received December 2004 Accepted August 2005 